\title{
Corticotropin-releasing hormone or dexamethasone regulates rat proopiomelanocortin transcription through Tpit/Pitx-responsive element in its promoter
}

\author{
Itsuo Murakami, Sakae Takeuchi, Toshiyuki Kudo ${ }^{\mathbf{1}}$, Shizuyo Sutou ${ }^{\mathbf{1}}$ and Sumio Takahashi \\ Department of Biology, Faculty of Science, Okayama University, 3-1-1, Tsusima-naka, Okayama 700-8530, Japan \\ ${ }^{1}$ Department of Biological Pharmacy, School of Pharmacy, Shujitsu University, Okayama 703-8516, Japan \\ (Requests for offprints should be addressed to S Takahashi; Email: stakaha@cc.okayama-u.ac.jp)
}

\begin{abstract}
Tpit/Pitx-responsive element (Tpit/PitxRE), which binds transcription factors Tpit and Pitx1, confers cell-type specific expression of proopiomelanocortin $(P O M C)$ gene in pituitary corticotrops where the gene expression is mainly regulated by corticotropin-releasing hormone $(\mathrm{CRH})$ and glucocorticoids (Gcs). CRH stimulates POMC gene expression, which is mediated by the accumulation of intracellular cAMP and requires binding of Nur factors to Nur-responsive element (NurRE). Gcs antagonize NurRE-dependent POMC gene expression through direct interaction between glucocorticoid receptors and Nur factors. We examined whether Tpit/PitxRE and NurRE are involved in CRH/cAMP-induced activation and Gc-induced repression of POMC gene expression by reporter assay in AtT-20 corticotropic cells. Deletion and mutation of Tpit/PitxRE markedly reduced basal activity of the promoter, and those of NurRE decreased the levels of the $\mathrm{CRH} / \mathrm{cAMP}-$ induced activation. Nifedipine, KN-62, and
\end{abstract}

W-7, specific inhibitors of the L-type calcium channel, calmodulin-dependent protein kinase II, and calmodulin respectively, attenuated CRH/cAMP-induced activation of promoters with three copies of either Tpit/PitxRE or NurRE, indicating that both Tpit/PitxRE and NurRE mediate CRHinduced activation of POMC gene expression in a calciumdependent manner. Deletion and mutation of Tpit/PitxRE abolished dexamethasone (DEX)-induced repression of POMC gene expression, while those of NurRE did not, indicating that Tpit/PitxRE predominantly mediates Gc-induced repression of POMC transcription. However, DEX treatment attenuated activities of promoters with three copies of either Tpit/PitxRE or NurRE, suggesting that Gcs act at NurRE as well as Tpit/PitxRE to repress $P O M C$ gene expression. We conclude that Tpit/PitxRE is an important element by which CRH and Gcs regulate the $P O M C$ gene expression.

Journal of Endocrinology (2007) 193, 279-290

\section{Introduction}

Expression of the proopiomelanocortin $(P O M C)$ gene in the pituitary gland is restricted to corticotropes in the anterior lobe and melanotropes in the intermediate lobe (Jeannotte et al. 1987, Drouin et al. 1989b). Cell-type specific expression of the POMC gene in corticotropes and melanotropes is maintained by the expression of Tpit (also called Tbx19), a Tbox family transcription factor, and pituitary homeobox 1 (Pitx1), a homeoprotein transcription factor. Tpit and Pitx1 bind to a cognate target sequence, Tpit/Pitx-responsive element (Tpit/PitxRE), activating POMC transcription (Lamolet et al. 2001). Tpit is crucial for late cell determination of corticotrophs and melanotrophs during pituitary development and is expressed exclusively in corticotrophs and melanotrophs (Lamolet et al. 2001, Pulichino et al. 2003a). Moreover, deficiency of Tpit in humans and mice is known to result in very low plasma adrenocorticotropin (ACTH) and corticosterone levels (Pulichino et al. 2003b).
Hypothalamic corticotropin-releasing hormone $(\mathrm{CRH})$ stimulates transcription of POMC and secretion of ACTH in vivo (Bruhn et al. 1984), in cultured anterior pituitary cells (Loeffler et al. 1986, Gagner \& Drouin 1987) and ACTHproducing pituitary tumor AtT-20 cells (Affolter \& Reisine 1985, Reisine et al. 1985, Boutillier et al. 1995). CRH binds to its specific receptor, CRH-R1 (Vita et al. 1993, Timpl et al. 1998), stimulating the accumulation of intracellular cAMP levels (Giguere et al. 1982, Aguilera et al. 1983, Litvin et al. 1984, Vita et al. 1993, Grammatopoulos \& Chrousos 2002), which is followed by the activation of protein kinase A (PKA) in corticotrophs (Reisine et al. 1985, Kovalovsky et al. 2002). PKA activation by CRH provokes an influx of extracellular calcium via L-type voltage-dependent calcium channels (Kuryshev et al. 1996, Lee \& Tse 1997), which in turn causes ACTH secretion (Lee \& Tse 1997). The influx of calcium causes the activation of calcium/calmodulin-dependent protein kinase II (CAM-KII; Kovalovsky et al. 2002). In addition to ACTH secretion, the calcium influx also induces the activation of POMC mRNA transcription 
(von Dreden et al. 1988) and POMC promoter activity (Kovalovsky et al. 2002). Activation of the PKA pathway also induces ERK1/2 (MAPK) cascade activation on POMC gene expression (Kovalovsky et al. 2002, Maira et al. 2003b).

POMC transcription depends on expression of Nur factors, Nur77 (also called NGF-IB), Nur-related factor 1 (Nurr1), and neuron-derived orphan receptor 1, which constitute a subfamily of nuclear orphan receptors. CRH enhances Nur77 expression and changes the phosphorylation status of Nur77, stimulating transcriptional activity of Nur77 in AtT-20 cells (Kovalovsky et al. 2002, Maira et al. 2003a). Activated Nur factors bind to the target DNA element in the POMC promoter, Nur-responsive element (NurRE), as a homo- or hetero-dimer (Maira et al. 1999, 2003a). CRHinduced NurRE-dependent POMC transcription is mediated via PKA/CAM-KII/ERK1/2 cascades in AtT-20 cells (Kovalovsky et al. 2002, Maira et al. 2003b).

In addition to Nur factors, Tpit mediates CRH-induced activation of POMC transcription, which involves the activation of cAMP and ERK1/2 signals (Maira et al. 2003b). Tpit recruits steroid receptor co-activator (SRC)/p160 co-activators in response to $\mathrm{CRH}$ stimulation, cooperating with Nur77, resulting in the assembly of a complex of transcription factors and co-activators on the POMC promoter, enhancing POMC transcription. However, involvement of the calcium influx in the activation of Tpit/PitxRE under CRH stimulation is not clear.

Adrenal glucocorticoids (Gcs) negatively regulate $\mathrm{CRH}$ transcription, POMC transcription and ACTH secretion (Birnberg et al. 1983, Eberwine \& Roberts 1984, Keller-Wood \& Dallman 1984, Gagner \& Drouin 1985, 1987, Drouin et al. 1989a, Farrell et al. 1993), establishing a negative feedback loop in the hypothalamus-pituitary-adrenal (HPA) axis. Gcs exert their biological activities by binding to a glucocorticoid receptor (GR), a member of the steroid receptor superfamily (Dostert \& Heinzel 2004), thus acting as a transcription factor; in the absence of Gcs, GR resides in the cytoplasm (Cadepond et al. 1991). When Gc binds to GR, the GR translocates to the nucleus (Picard \& Yamamoto 1987), where the hormonebound GRs directly bind to a specific DNA sequence, glucocorticoid-response element (GRE), as a homo-dimer, activating target gene transcription with basal transcription machinery. GRs also repress gene transcription by binding to a specific DNA element, negative GRE (nGRE; Kumar \& Thompson 2005) or physical association with other transcription factors, such as activator protein 1 (AP-1) or nuclear factor $\kappa \mathrm{B}(\mathrm{NF}-\kappa \mathrm{B}$; De Bosscher et al. 2003). Interaction of GR with AP-1 or NF- $\kappa$ B clearly accounts for the immunosuppressive actions of Gcs since it is well known that Gcs dramatically inhibit transcription of many mediators of the inflammatory response such as cytokines and chemokines whose expression is upregulated by AP-1 and/or NF- $\mathrm{B}$ (De Bosscher et al. 2003).

Previous studies have demonstrated that the opposing effects of CRH and Gcs on POMC transcription are mediated by NurRE in the POMC promoter. Gcs repress CRH-induced Nur77 mRNA expression (Philips et al. 1997b). Gcs also repress
NurRE-mediated POMC transcription through physical interaction between Nur factors and GR (Martens et al. 2005). It is thought that a direct interaction between GR and Nur factors occurs via the respective DNA-binding domains, resulting in the suppression of NurRE-dependent transcription. However, it is not clear whether Tpit/PitxRE is involved in the Gc-induced repression of POMC transcription.

The aim of the present study is to clarify the mechanism of Tpit/PitxRE-mediated POMC promoter regulation. In particular, the possibilities of calcium-dependent activation of Tpit/PitxRE and Tpit/PitxRE-dependent repression of $P O M C$ gene transcription by Gcs were examined. We found that Tpit/PitxRE mediates CRH-induced POMC gene transcription via a calcium-dependent CAM-KII pathway. Furthermore, we revealed that Tpit/PitxRE is a predominant target sequence of Gc-mediated repression of POMC gene transcription.

\section{Materials and Methods}

\section{Reagents}

Human/rat CRH was purchased from the Peptide Institute (Osaka, Japan) and 8-(4-chlorophenylothio) adenosine $3^{\prime}, 5^{\prime}$ cyclic monophosphate (pCPT-cAMP) and dexamethasone (DEX) from Sigma-Aldrich. A specific inhibitor of the L-type calcium channel, nifedipine (NIF) was obtained from Nacalai Tesque (Kyoto, Japan), a specific inhibitor of (CAMKII), KN-62, from WAKO Chemical (Osaka, Japan), and a specific inhibitor of calmodulin, W-7, from Calbiochem (San Diego, CA, USA). All reagents were dissolved in culture medium immediately before use.

\section{Cell culture}

AtT-20/D16v-F2 cells were obtained from the American Type Culture Collection (Manassas, VA, USA). Cells were cultured in Dulbecco's modified Eagle's medium (DMEM; Sigma-Aldrich) containing $2 \mathrm{mM}$ L-glutamine and $25 \mathrm{mM}$ glucose supplemented with $10 \%(\mathrm{v} / \mathrm{v})$ heat-inactivated fetal calf serum at $37{ }^{\circ} \mathrm{C}$ in a humidified atmosphere of $5 \% \mathrm{CO}_{2}-$ $95 \%$ air. For luciferase measurement, cells were plated in 12-well plates (BD Biosciences, Bedford, MA, USA) at $2 \cdot 5 \times$ $10^{5}$ cells and allowed to adhere for $24 \mathrm{~h}$. For mRNA measurement, cells were plated into six-well plates (BD Biosciences) at $6 \cdot 5 \times 10^{5}$ cells and cultured for $24 \mathrm{~h}$ prior to DEX treatment.

\section{Plasmid construction}

A POMC $-480 /+63$ construct, $5^{\prime}$ deletion constructs (POMC $-379 /+63$, POMC $-292 /+63$, and POMC $-34 /+63$ ), and site-directed mutation constructs (POMC NurREmut, POMC TpitREmut, and POMC PitxREmut) were prepared as follows. A nucleotide fragment of the rat 
POMC gene containing $480 \mathrm{bp}$ of the $5^{\prime}$ flanking region and $63 \mathrm{bp}$ of exon 1 was amplified by PCR with Pfx DNA polymerase (Invitrogen Corp.) and subcloned into the MluI and SmaI sites of pGL3-Basic Vector (Promega Corp.), upstream of the firefly luciferase gene. The transcription start site was numbered +1 . The $5^{\prime}$ deletion fragments were synthesized by PCR, with specific primers for each deletion construct, using the POMC $-480 /+63$ construct as a template, and the PCR products were subcloned into the pGL3-Basic Vector. Sitedirected mutation fragments were obtained through PCR using primers incorporating the required substitutions. The nucleotide sequence substitutions were as follows: NurREmut (from TGATATTTACCTCCAAATGCCA to cagcgcccACCTCCgggectCA; Mynard et al. 2004), TpitREmut (from TCACACCA to gacgcaat), and PitxREmut (from TAAGCC to acttag); lower case letters indicate the mutations. The fragments were subcloned into the MluI and SmaI sites of the pGL3-Basic Vector. A (NurRE) $\times 3$ and (Tpit/PitxRE) $\times 3$ reporter fused to the rat POMC $-34 /+63$ construct were synthesized by PCR amplification of synthetic oligonucleotides followed by subcloning upstream of the rat POMC $-34 /+63$ construct. The nucleotide sequence of each tandem repeat was as follows: (NurRE) $\times 3$ (TAGTGATATTTACCTCCAAATGCCAGGA, the NurRE sequence is underlined) $\times 3$ and (Tpit/PitxRE) $\times 3$ (GCCTCACACCAGGATGCTAAGCCTCT, the TpitRE sequence is underlined first and the PitxRE sequence next) $\times 3$. The phRL-TK Vector, used as an internal control in the dual luciferase assay, was purchased from Promega. All plasmids were sequenced for verification.

\section{Transient transfection}

AtT-20 cells were transfected using Lipofectamine 2000 (Invitrogen) at a ratio of $2.5 \mu \mathrm{l}: 1 \mu \mathrm{g}$ DNA according to the manufacturer's instructions in DMEM supplemented with insulin-transferrin-selenium-G (ITS-G) supplement (Invitrogen). Each well contained $500 \mathrm{ng}$ POMC promoter luciferase-reporter plasmid and $2.5 \mathrm{ng}$ phRL-TK Vector. Twenty-four hours after transfection, the cells were treated with CRH $(100 \mathrm{nM})$ or pCPT-cAMP $(500 \mu \mathrm{M})$ for $4 \mathrm{~h}$ prior to harvesting, and with NIF $(1 \mu \mathrm{M}), \mathrm{KN}-62(10 \mu \mathrm{M})$, or W-7 $(10 \mu \mathrm{M})$, for $1 \mathrm{~h}$ before CRH or pCPT-cAMP treatment. For harvesting, cells were washed with PBS and lysed with passive lysis buffer (Promega) and the luciferase activity was measured using the Dual Luciferase Reporter Assay System (Promega) with the TD-20/20 Luminometer (TURNER DESIGNS, Sunnyvale, CA, USA) according to the manufacturer's instructions. For DEX treatment, AtT-20 cells were treated with DEX $(100 \mathrm{nM})$ in DMEM supplemented with ITS-G supplement, and then transfected with Lipofectamine 2000 as described above for $24 \mathrm{~h}$ following transfection. The cells were then washed with PBS and lysed with passive lysis buffer. The cell lysate was assayed for luciferase activity using the Luciferase Assay System (Promega). The concentration of the total cell protein was determined using Coomassie Plus Bradford Assay Kit (Pierce, Rockford, IL, USA), and the luciferase activity was normalized to the amount of protein, because Renilla luciferase activity of phRL-TK vector was decreased by DEX treatment (for details see 'Results'), and the protein contents did not appear to be affected by DEX treatment.

\section{Determination of POMC, Tpit, and Pitx1 $\mathrm{mRNA}$ levels}

AtT-20 cells were treated with DEX $(100 \mathrm{nM})$ in DMEM supplemented with ITS-G supplement for $24 \mathrm{~h}$. Total RNA from AtT-20 cells was prepared using TRIzol reagent (Invitrogen), according to the manufacturer's instructions. One microgram of RNA was subjected to reverse transcription reaction using the ThermoScript RT-PCR system (Invitrogen) with the Oligo-dT primer according to the manufacturer's instructions. The sequence of primers used for mouse POMC, Tpit, Pitx1, and ribosomal protein L-19 were as follows: POMC sense, 5'-ATAGATGTGTGGAGCTGGTGCC-3'; POMC antisense, $5^{\prime}$-CTTCCAGCTCCCTCTTGAACTC- $3^{\prime}$; Tpit sense, 5'-GCCAGCATGTGACCTACTCTCACT-3'; Tpit antisense, 5'-AGTCCAGCTGTCAGGTCCCGAGAA-3'; Pitx1 sense, $5^{\prime}$-CGGTGTGGACCAACCTCACTGAA-3'; Pitx1 antisense, 5'-GAGTTGCACGTGTCCCGGTAGA-3'; L-19 sense, 5'-GAAATCGCCAATGCCAACTC- $3^{\prime}$; and L-19 antisense, TCTTAGACCTGCGAGCCTCA-3'. PCR was carried out using TaKaRa Taq DNA polymerase (TAKARA Bio INC., Otsu, Japan). The temperature cycle conditions were as follows: Tpit and Pitx1, denaturation at $94^{\circ} \mathrm{C}$ for 30 s and extension at $60^{\circ} \mathrm{C}$ for $30 \mathrm{~s}$; POMC and L-19, denaturation at $94^{\circ} \mathrm{C}$ for $30 \mathrm{~s}$, annealing at $55^{\circ} \mathrm{C}$ for $30 \mathrm{~s}$, and extension at $72{ }^{\circ} \mathrm{C}$ for $30 \mathrm{~s}$. POMC cDNA fragments were amplified over 18 cycles, Tpit cDNA fragments were amplified over 23 cycles, Pitx1 cDNA fragments were amplified over 29 cycles, and L-19 cDNA fragments were amplified over 20 cycles. Ten microliters of PCR products were electrophoresed onto $1.5 \%(\mathrm{w} / \mathrm{v})$ agarose gel in Tris-acetate-EDTA buffer, stained with ethidium bromide, and photographed under u.v. illumination and compared with a known standard (100-bp DNA Ladder, New England Biolabs, Inc., Beverly, MA, USA).

\section{Statistical analysis}

Data are presented as means \pm standard errors of means ( \pm S.E.M.) of three samples. Statistical analyses were performed with the Tukey-Kramer test to compare the means of multiple groups. The Dunnet's test was used to compare experimental groups with the control group.

\section{Results}

POMC promoter activation by $C R H$ and $C A M P$

We found that 10 and $100 \mathrm{nM}$ CRH activated luciferase activity of the POMC $-480 /+63$ construct in the doseresponse experiment (Fig. 1A) and the maximum response was 
A

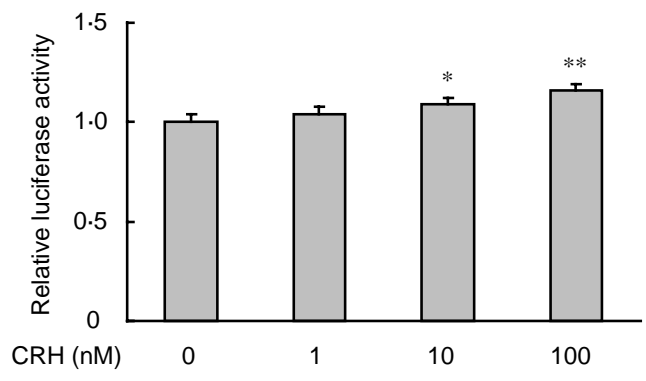

B

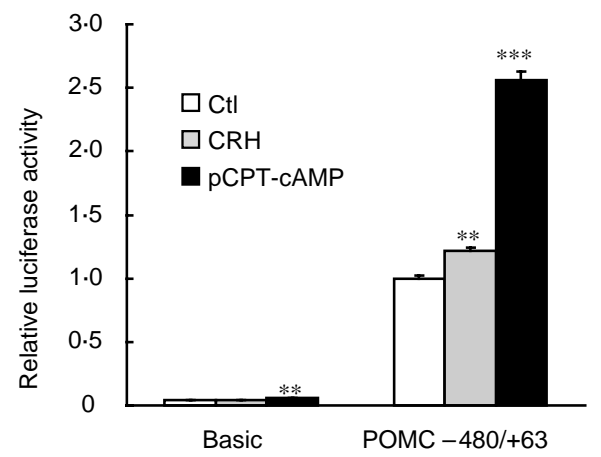

$\mathrm{C}$

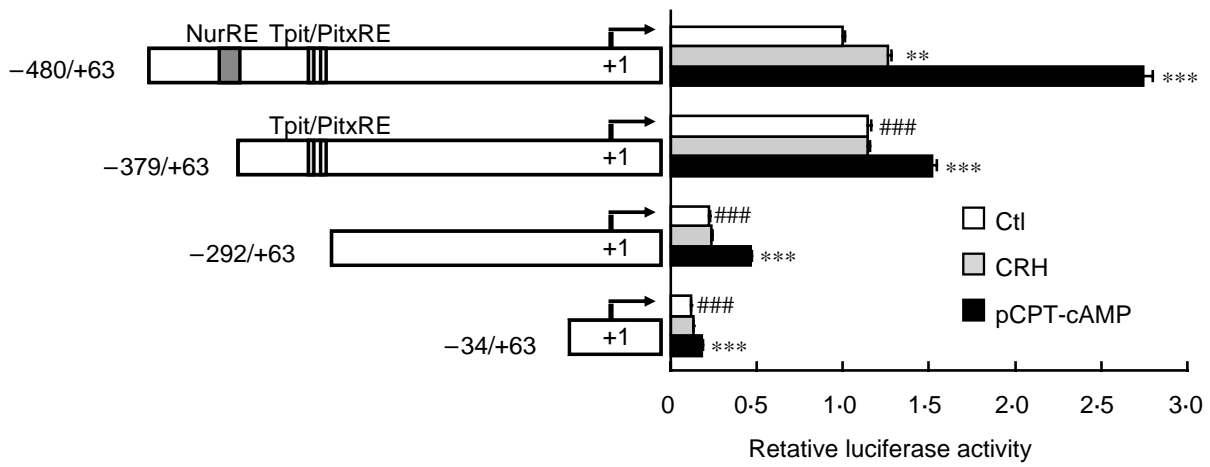

D

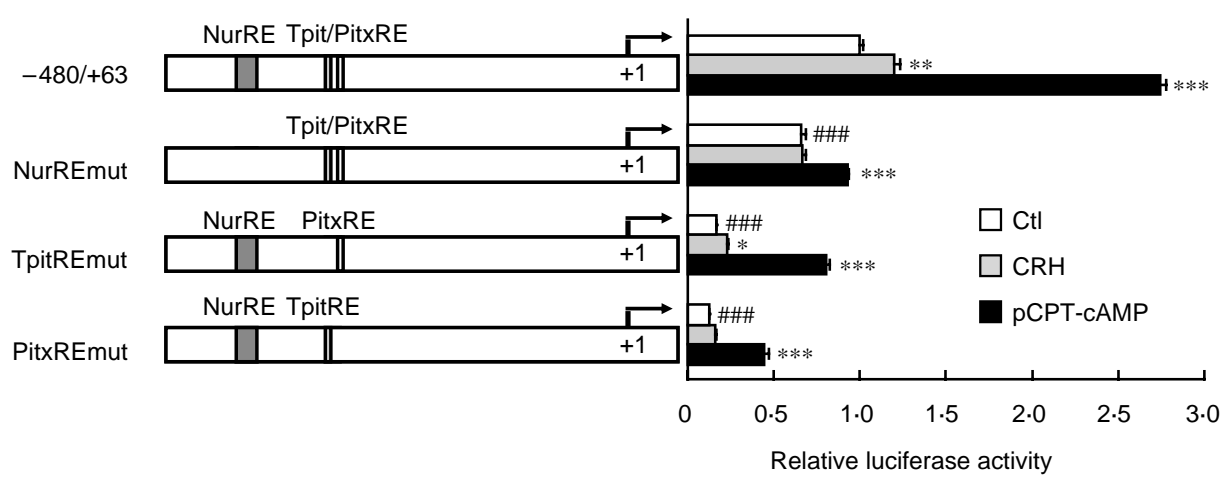

Figure 1 Search for $\mathrm{CRH}$ - and cAMP-responsive promoter region of rat POMC gene in AtT-20 cells. (A) AtT-20 cells were transiently transfected with POMC $-480 /+63$ construct in addition to phRL-TK Vector and cultured for $24 \mathrm{~h}$. Cells were stimulated for $4 \mathrm{~h}$ with the indicated concentration of $\mathrm{CRH}$. (B) AtT-20 cells were transiently transfected with pGL3-Basic Vector or POMC $-480 /+63$ construct in addition to phRL-TK Vector and cultured for $24 \mathrm{~h}$. Cells were stimulated for $4 \mathrm{~h}$ with $100 \mathrm{nM}$ CRH or $500 \mu \mathrm{M}$ pCPT-CAMP. (C) 5 ' Deletion fragments of rat POMC promoter (POMC $-480 /+63$, POMC $-379 /+63$, POMC $-292 /+63$, POMC - 34/+63) were fused to luciferase reporter gene. Transfected cells were treated with $100 \mathrm{nM}$ CRH or $500 \mu \mathrm{M} \mathrm{pCPT-cAMP}$ for 4 h. (D) AtT-20 cells were transfected with wild-type (POMC - 480/+63) and site-directed mutant (POMC NurREmut, POMC TpitREmut and POMC PitxREmut) constructs. Cells were treated as mentioned above. The luciferase activity of cell lysate was measured and normalized to Renilla luciferase activity. Luciferase activity was expressed as fold change of the activity relative to the control (Ctl) level of POMC $-480 /+63$ construct. The results are shown as means \pm S.E.M. $(n=3)$. Three independent experiments were performed with similar results. ${ }^{*} P<$ $0 \cdot 05,{ }^{* *} P<0 \cdot 01,{ }^{* * *} P<0 \cdot 001$, significantly different from the level of respective control $(\mathrm{Ctl}) .{ }^{\# \#} P<0 \cdot 001$, significantly different from the level of POMC $-480 /+63$ construct. 
detected $4 \mathrm{~h}$ after stimulation with $\mathrm{CRH}$ in the time-course experiment (data not shown). Since CRH-induced activation of the POMC promoter was weak, a membrane-permissive cAMP analog, pCPT-cAMP was used. Luciferase activity of the POMC $-480 /+63$ construct was significantly stimulated by CRH $(100 \mathrm{nM})$ and pCPT-cAMP $(500 \mu \mathrm{M}) 4 \mathrm{~h}$ after each treatment. In the control experiment, the luciferase activity of the pGL3-Basic Vector was not stimulated by CRH, but was activated by pCPT-cAMP (Fig. 1B).

Roles of NurRE and Tpit/PitxRE in CRH- and CAMPinduced activation of the POMC promoter

To elucidate the roles of NurRE and Tpit/PitxRE in CRHand cAMP-induced activation of the POMC promoter, a series of deletion reporters containing the rat POMC promoter region were generated, and then transfected AtT20 cells were treated with CRH or pCPT-cAMP. Basal promoter activities of the POMC $-379 /+63$ construct, which lacked NurRE, were slightly higher than those of the POMC $-480 /+63$ construct, but those of the POMC $-292 /+63$ construct, which lacked NurRE and Tpit/PitxRE, and the POMC $-34 /+63$ construct, which contained the TATA box and part of exon 1, were lower (Fig. 1C). Each deletion construct lost responsiveness to CRH, but cAMP-induced activation was still detected, although the magnitude of the response was reduced. Sitedirected mutation of NurRE (POMC NurREmut) significantly decreased the basal promoter activity when compared with the $-480 /+63$ construct, completely abolished POMC promoter activation by $\mathrm{CRH}$, and considerably reduced promoter activation in response to cAMP treatment (Fig. 1D). Mutation of TpitRE (POMC TpitREmut) or PitxRE (POMC PitxREmut) markedly diminished basal promoter activity. In the POMC TpitREmut construct, CRH- and cAMP-induced activation of the POMC promoter was detected. In the POMC PitxREmut construct, significant CAMP-induced activation was detected but CRHinduced activation was not detected.

Calcium involvement in activation of NurRE and Tpit/PitxRE by $C R H$ and $C A M P$

To examine whether a calcium influx is required for NurRE and Tpit/PitxRE activation through the CRH/cAMP pathway, we prepared (NurRE) $\times 3$ and (Tpit/PitxRE) $\times 3$ constructs containing three tandem repeats of NurRE and Tpit/PitxRE respectively, in front of the $\mathrm{PPOMC}-34 /+63$ construct. $\mathrm{CRH}$ and pCPT-cAMP treatment increased the luciferase activity of (NurRE) $\times 3$ and (Tpit/PitxRE) $\times 3$ constructs (Figs 2 and 3). Pretreatment of AtT-20 cells with NIF, a specific inhibitor of the L-type calcium channel, decreased CRH- and pCPT-cAMP-induced activation of luciferase activity of the (NurRE) $\times 3$ construct (Fig. 2A). Pretreatment of AtT-20 cells with KN-62, a specific inhibitor of CAM-KII, decreased the pCPT-cAMP-induced activation of luciferase activity of the
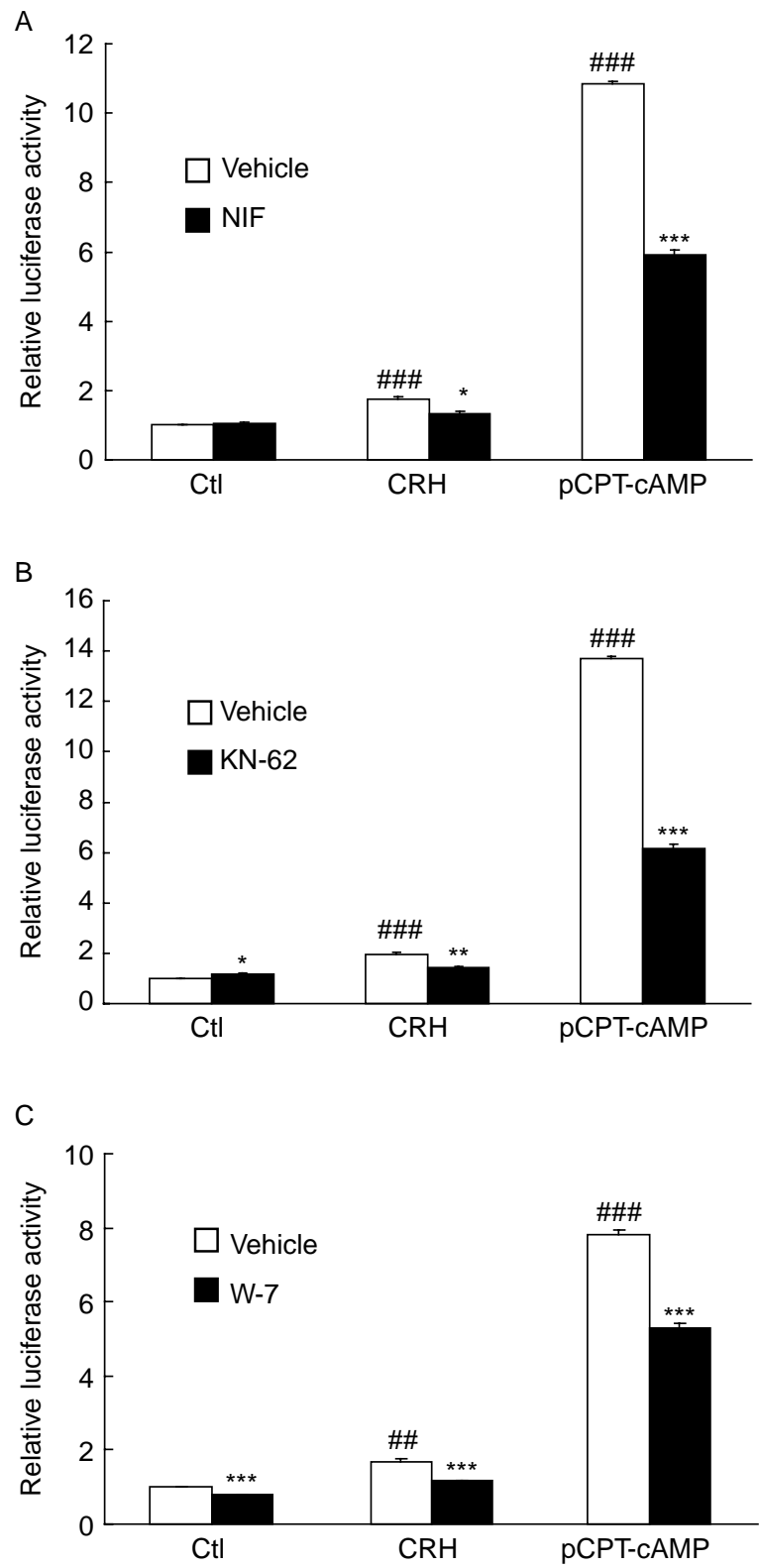

Figure 2 Effect of nifedipine, $\mathrm{KN}-62$, and $\mathrm{W}-7$ on luciferase activity of (NurRE) $\times 3$ construct. (A) AtT-20 cells were transfected with reporter construct $(($ NurRE$) \times 3)$ containing three copies of NurRE inserted upstream of POMC $-34 /+63$. After $24 \mathrm{~h}$, transfected cells were pretreated with $(\mathrm{A})$ the L-type calcium channel inhibitor, nifedipine (NIF, $1 \mu \mathrm{M})$, (B) the inhibitor of CAM-KII, KN-62 $(10 \mu \mathrm{M})$, or $(\mathrm{C})$ the calmodulin inhibitor, $\mathrm{W}-7(10 \mu \mathrm{M})$ for $1 \mathrm{~h}$, and then stimulated with $100 \mathrm{nM} \mathrm{CRH}$ or $500 \mu \mathrm{M}$ pCPT-cAMP. After $4 \mathrm{~h}$ cultivation, dual luciferase assay was performed. Data are the means \pm s.E.M. of triplicate determinations. Experiments were replicated three times with separate batches of cell preparations. ${ }^{\#} P<0 \cdot 01,{ }^{\# \#} P<0 \cdot 001$, significantly different from the level of control (Ctl). ${ }^{*} P<0 \cdot 05,{ }^{* *} P<0 \cdot 01,{ }^{* * *} P<0 \cdot 001$, significantly different from the level of vehicle-treated group. 

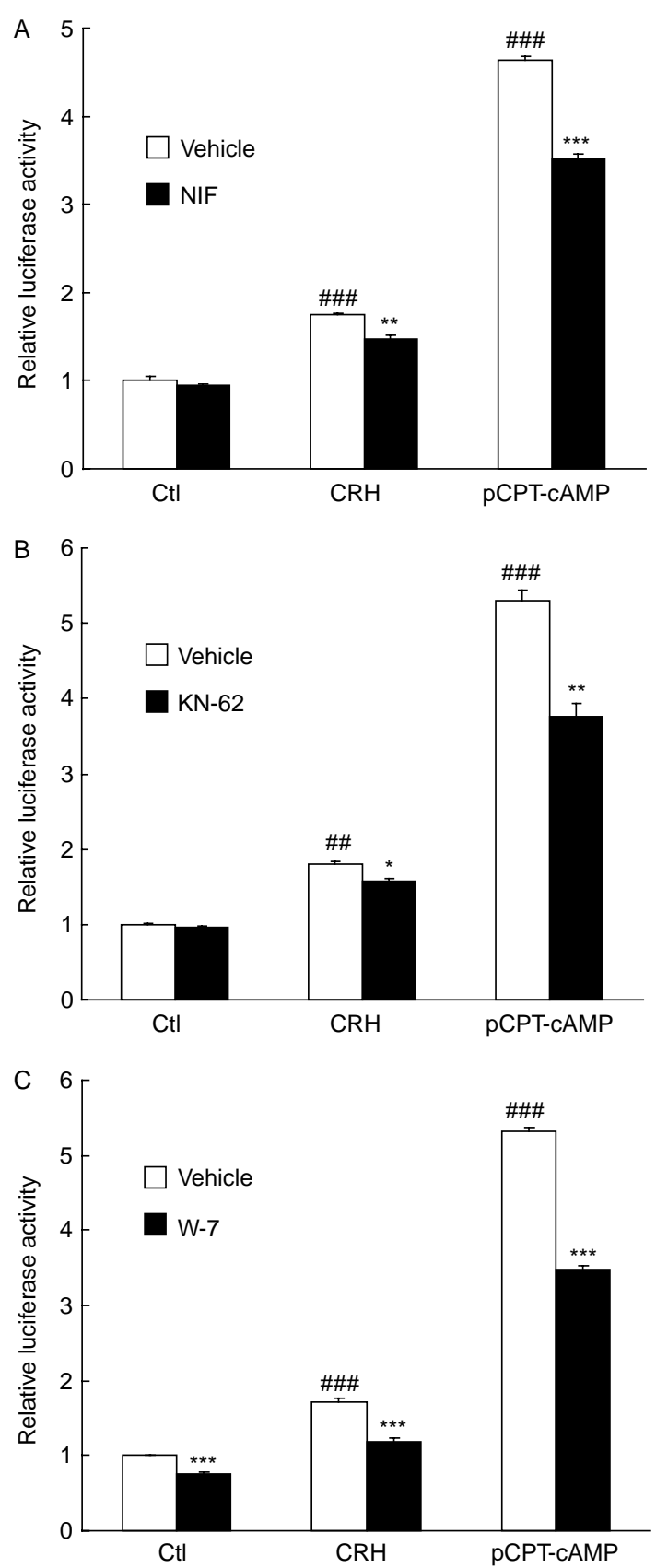

Figure 3 Effect of nifedipine, $\mathrm{KN}-62$, and $\mathrm{W}-7$ on luciferase activity of (Tpit/PitxRE) $\times 3$ construct. (A) AtT-20 cells were transfected with reporter construct $((\mathrm{Tpit} / \mathrm{PitRE}) \times 3)$ containing three copies of Tpit/PitxRE inserted upstream of POMC $-34 /+63$. After $24 \mathrm{~h}$, transfected cells were pretreated with (A) the L-type calcium channel inhibitor, nifedipine (NIF, $1 \mu \mathrm{M}$ ), (B) the inhibitor of CAM-KII, KN-62 $(10 \mu \mathrm{M})$, or $(\mathrm{C})$ the calmodulin inhibitor, $\mathrm{W}-7(10 \mu \mathrm{M})$ for $1 \mathrm{~h}$, and then stimulated with $100 \mathrm{nM}$ CRH or $500 \mu \mathrm{M}$ pCPT-CAMP. After $4 \mathrm{~h}$ cultivation, dual luciferase assay was performed. Data are the means \pm s.E.M. of triplicate determinations. Experiments were replicated three times with separate batches of cell preparations. ${ }^{\#} P<0 \cdot 01, \# \# P<0 \cdot 001$, significantly different from the level of control (Ctl). ${ }^{*} P<0 \cdot 05,{ }^{* *} P<0 \cdot 01, * * * P<0 \cdot 001$, significantly different from the level of vehicle-treated group.
(NurRE) $\times 3$ construct in a dose-dependent manner (data not shown). KN-62 at $10 \mu \mathrm{M}$ attenuated CRH- and pCPTcAMPinduced activation of the (NurRE) $\times 3$ construct, although KN-62 alone brought about a slight increase in NurRE activity (Fig. 2B). To confirm that NurRE was activated in a CAM-KIIdependent manner, we used a calmodulin inhibitor, W-7. Pretreatment of W-7 dose-dependently abolished pCPTcAMP-induced activation of (NurRE) $\times 3$ construct (data not shown). W-7 at $10 \mu \mathrm{M}$ inhibited CRH- and pCPTcAMPinduced activation of (NurRE) $\times 3$ construct (Fig. 2C). We tested the effects of NIF, KN-62, and W-7 on the response of the (Tpit/PitxRE) $\times 3$ construct under stimulation of $\mathrm{CRH}$ and pCPT-cAMP (Fig. 3A-C) revealing reduced CRH- and pCPTcAMP-induced activation of the (Tpit/PitxRE) $\times 3$ construct.

\section{DEX repression of $\mathrm{POMC}$ promoter activity}

DEX is known to be a potent inhibitor of POMC transcription and POMC promoter activity. We carried out dual luciferase assay to examine DEX-induced POMC repression, but the DEX effect seemed weak (Fig. 4A), because when protein concentration was used for normalization, DEX inhibited promoter activity of both the rat POMC $-480 /+63$ construct and phRL-TK vector (Fig. 4B and C). An alternative internal control reporter, phRL-SV40 vector, was employed, but its luciferase activity was also attenuated by DEX treatment (data not shown). We considered that dual luciferase assay was not suitable for DEX treatment experiments, and normalization using protein concentration was more appropriate. In the following experiments, firefly luciferase activities were normalized by protein concentration.

DEX inhibited the promoter activity of the POMC $-480 /+63$ construct by $50 \%$, but did not inhibit the activity of the pGL3-Basic Vector (Fig. 5A), indicating that DEX inhibits the POMC promoter activity. In the deletion experiments, DEX-induced inhibition was observed in the POMC $-480 /+63$ and $-379 /+63$ constructs, but no repressive effect of DEX was observed in the POMC $-292 /+63$ and $-34 /+63$ constructs (Fig. 5B). In the site-directed mutation experiments, DEX repressed promoter activity of the POMC $-480 /+63$ and POMC NurREmut constructs, but not the POMC TpitREmut and POMC PitxREmut constructs (Fig. 5C).

The results of the deletion and site-directed mutation experiments suggest an obvious difference between NurRE and Tpit/PitxRE with regard to responsiveness to DEX. We therefore tested whether the promoter activity of (NurRE) $X$ 3 and (TpitRE) $\times 3$ constructs is inhibited by DEX treatment (Fig. 6); a significant decease was observed.

\section{Tpit and Pitx $1 \mathrm{mRNA}$ levels in DEX-treated AtT-20 cells}

Since DEX inhibited Tpit/PitxRE-mediated POMC transcription, we tested whether DEX affected the expression of Tpit and Pitx1 mRNA using semi-quantitative RT-PCR. In AtT-20 cells, DEX treatment decreased the POMC mRNA 

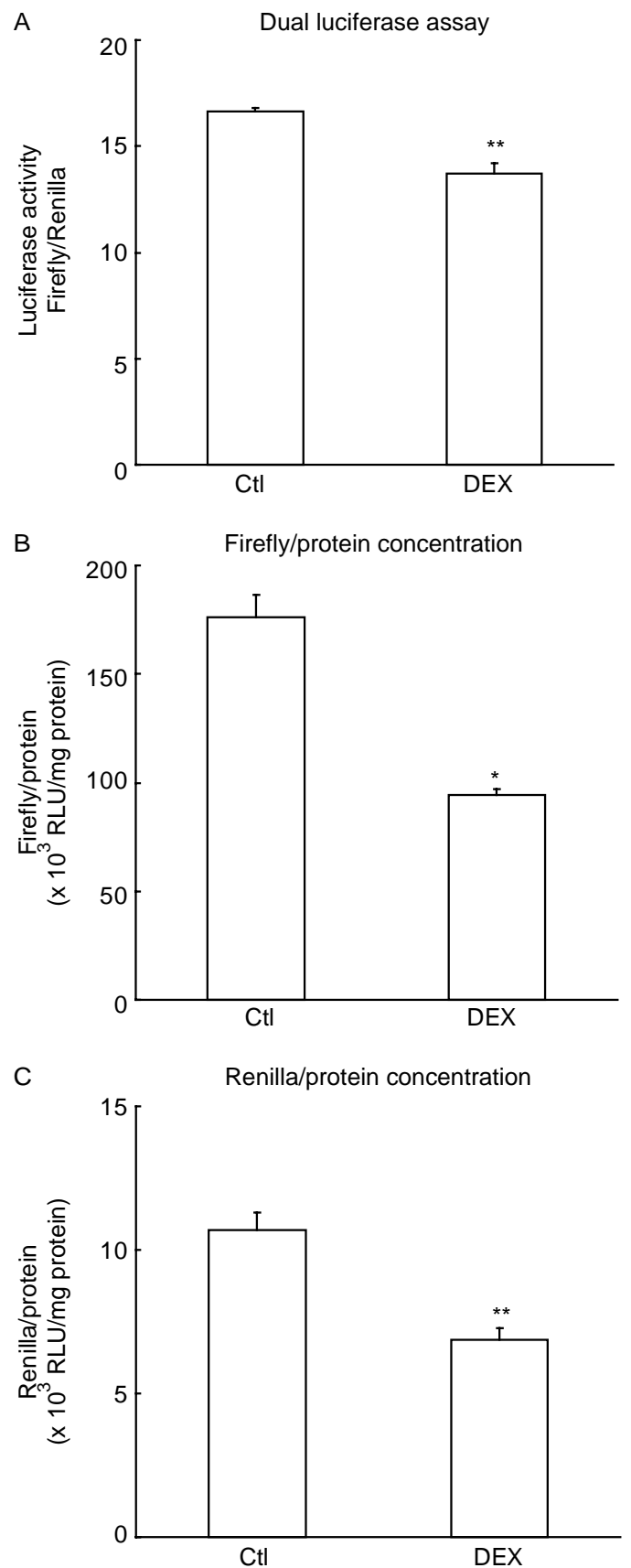

Figure 4 The appropriateness about normalization using protein concentration was studied. (A) AtT-20 cells were transiently transfected with $500 \mathrm{ng}$ rat POMC $-480 /+63$ construct, $2.5 \mathrm{ng}$ phRL TK plasmid in the presence of $10^{-7} \mathrm{M}$ DEX. After $24 \mathrm{~h}$, dual luciferase assay was performed. The values of firefly luciferase activity (POMC $-480 /+63$ construct) (B) and Renilla luciferase activity $(\mathrm{C})$ were normalized by protein concentration of cell lysate. The results were shown as means \pm s.E.M. of triplicate determinations. Experiments were replicated more than three times with separate batches of cell preparations. ${ }^{*} P<0 \cdot 05,{ }^{* *} P<0 \cdot 01$, significantly different from the level of respective control (Ctl). level at $24 \mathrm{~h}$, but Tpit and Pitx1 mRNA levels did not differ between the vehicle-treated and DEX-treated groups (Fig. 7).

\section{Discussion}

Previous studies have suggested that $\mathrm{CRH}$ enhances POMC transcription in an Nur factor- and NurRE-dependent manner (Philips et al. 1997b, Maira et al. 2003a), while Gcs attenuate POMC transcription through antagonism with Nur factors, thus diminishing the transcriptional activity of NurRE (Martens et al. 2005). The present study indicates that Tpit/PitxRE in the POMC promoter is responsible for $\mathrm{CRH}$ stimulation through a calcium-dependent pathway. Furthermore, we demonstrated for the first time that Tpit/PitxRE predominantly mediates Gc-induced repression of POMC transcription. These findings provide new insight into our understanding of the mechanisms by which CRH and Ges regulates the POMC transcription.

A stimulatory effect of $\mathrm{CRH}$ on POMC transcription and $\mathrm{ACTH}$ secretion is well established. The rat POMC promoter $-480 /+63$ construct is sufficient for corticotroph-specific POMC expression (Jeannotte et al. 1987, Hammer et al. 1990), and is activated by CRH and cAMP stimulation (Kovalovsky et al. 2002). Here, we found that CRH stimulated the rat POMC promoter $-480 /+63$ construct, while pCPT-cAMP stimulated the rat POMC promoter $-480 /+63$ construct to a large degree. This result coincides with those of previous reports (Jeannotte et al. 1987, Ray et al. 1996, Kovalovsky et al. 2002, Mynard et al. 2004). The low promoter activation of $\mathrm{CRH}$ treatment might be due to low cAMP generation, because there are some reports that described low and transient cAMP accumulation on CRH stimulation in AtT-20 cells (Litvin et al. 1984, Nikodemova et al. 2003). On the other hand, Aoki et al. (1997) reported much greater POMC promoter activation in response to $\mathrm{CRH}$. The difference in the response of rat POMC promoter to CRH between the data from Aoki et al. (1997) and ours might be due to the difference in transfection protocols employed; they used the stable transfection protocol with pA3 luciferase reporter plasmids, while we used the transient transfection protocol with pGL3 luciferase reporter plasmids. The transient transfection in the present study is considered to result in the occurrence of low response of the rat POMC promoter to $\mathrm{CRH}$.

Tpit expression is essential for POMC expression specific to corticotrophs and melanotrophs (Pulichino et al. 2003b). Previous study demonstrated that Tpit-bound Tpit/PitxRE probe in vitro, and mutation of Tpit/PitxRE in the intact POMC promoter context resulted in a loss of Tpit- and Pitx1-induced POMC promoter activation in heterogeneous cells (Lamolet et al. 2001). We demonstrated here for the first time that deletion of Tpit/PitxRE (POMC -292/+63) and site-directed mutation of Tpit/PitxRE (POMC TpitREmut and PitxREmut) result in a decrease in the basal activity of the POMC promoter $-480 /+63$ construct in AtT-20 cells. These results indicate that Tpit/PitxRE is 
A

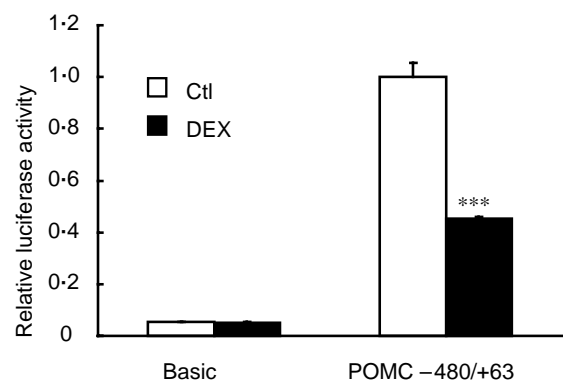

B

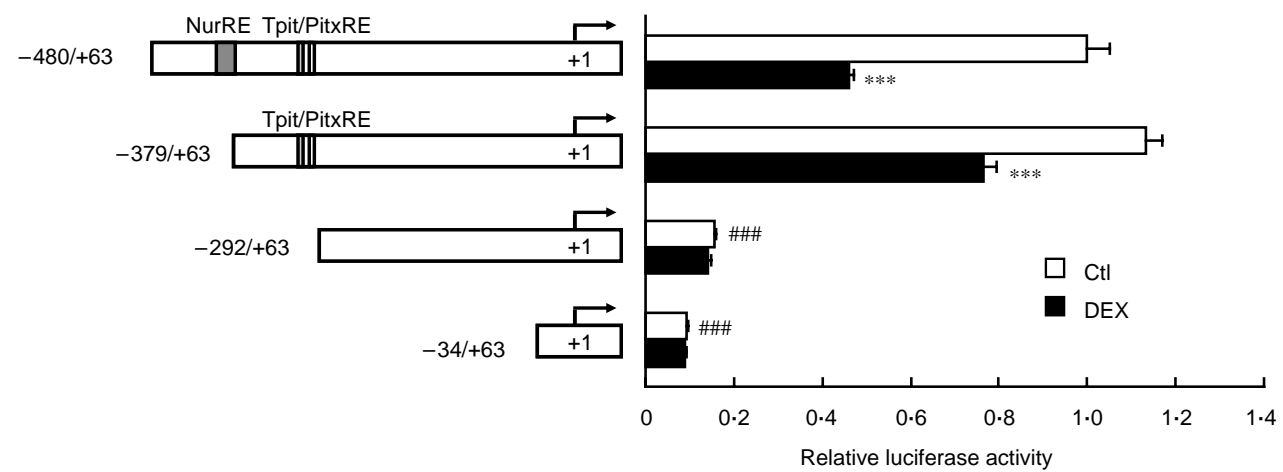

C

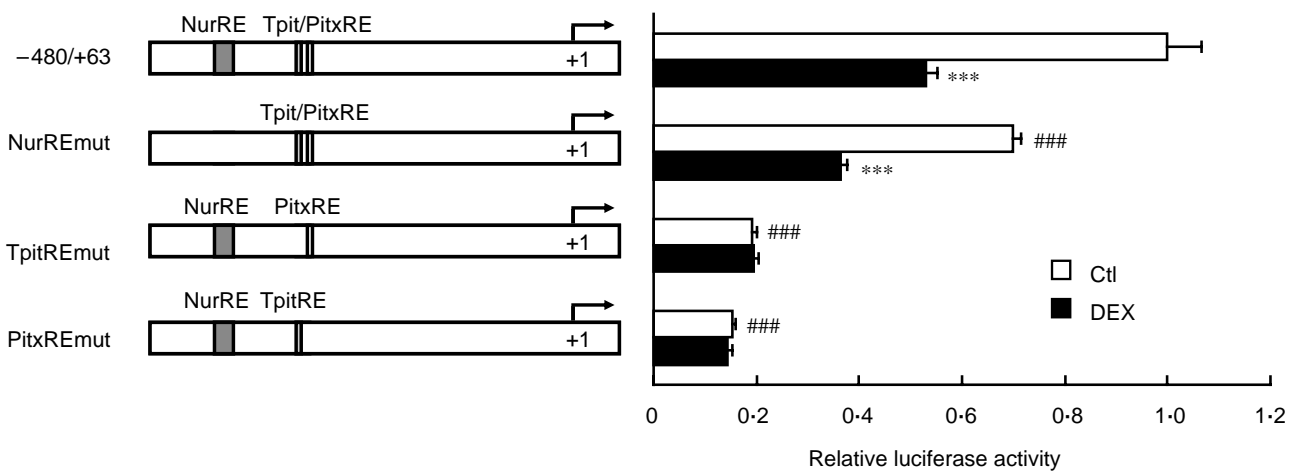

Figure 5 Search for DEX-responsive promoter region of rat POMC gene in AtT-20 cells. (A) AtT-20 cells were transiently transfected with pGL3-Basic Vector or POMC $-480 /+63$ construct in the presence of $100 \mathrm{nM}$ DEX for $24 \mathrm{~h}$. Luciferase activity of cell lysate was determined and protein concentration of cell lysate was measured for internal control. AtT-20 cells were transfected with $5^{\prime}$-deletion mutated (B) or site-directed mutated constructs (C) of rat POMC promoter in the presence of $100 \mathrm{nM} \mathrm{DEX}$ for $24 \mathrm{~h}$. The luciferase activity of cell lysate was determined as mentioned above. The results were shown as means \pm S.E.M. of triplicate determinations. Experiments were replicated more than three times with separate batches of cell preparations.

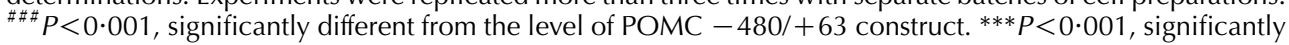
different from the level of vehicle-treated group (control (Ctl).

required for the regulation of POMC promoter activity, suggesting that TpitRE is a factual target region of Tpit binding, and interaction between Tpit and Pitx1 with Tpit/ PitxRE is indispensable for cell-type specific expression of the $P O M C$ gene. A previous study of transgenic mice in which the rat POMC promoter from -323 to -34 region was knocked in suggests that the POMC promoter $-323 /-34$ region is necessary for pituitary-specific POMC expression (Liu et al. 1992). As the POMC promoter $-323 /-34$ contains Tpit/PitxRE, Tpit/PitxRE might be an important sequence for cell-type specific $P O M C$ gene expression. 


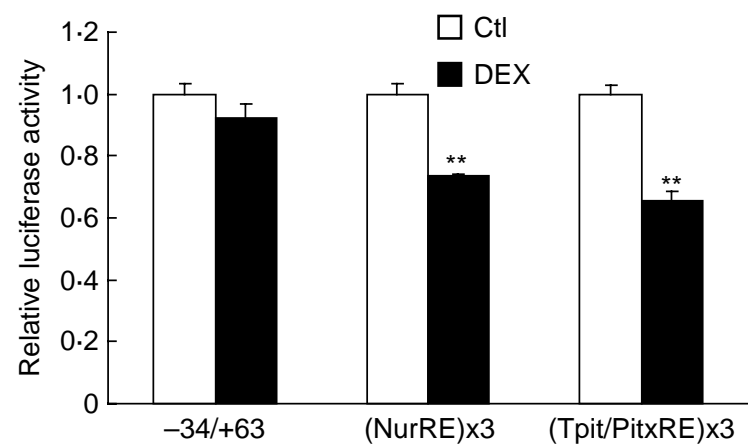

Figure 6 AtT-20 cells were transfected with (NurRE) $\times 3$ or (Tpit/PitxRE) $\times 3$ construct in the presence of $100 \mathrm{nM}$ DEX for $24 \mathrm{~h}$. The luciferase activity of cell lysate was determined as mentioned in Fig. 5. The results were shown as means \pm s.E.M. of triplicate determinations. Experiments were replicated more than three times with separate batches of cell preparations. ${ }^{* *} P<0 \cdot 01$, significantly different from the level of vehicle-treated group (control $(\mathrm{Ctl})$ ).

Deletion and site-directed mutation analyses of the rat POMC promoter in the present study also showed a key role of NurRE in CRH- and cAMP-induced activation of POMC transcription, since deletion of NurRE (POMC $-379 /+63$ ) and site-directed mutation of NurRE (POMC NurREmut) completely abolished responsiveness to $\mathrm{CRH}$ and reduced responsiveness to $\mathrm{pCPT-cAMP}$. These observations coincide
A

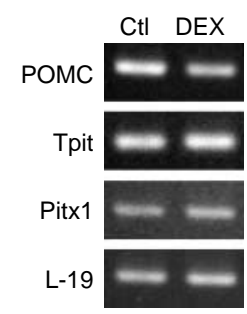

C

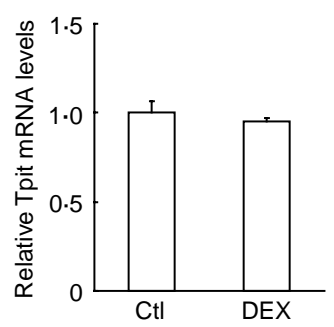

B

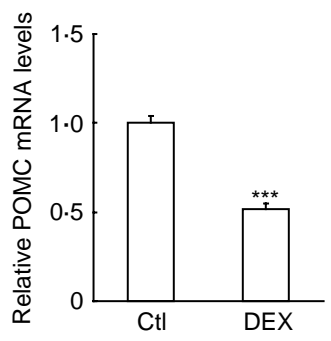

D

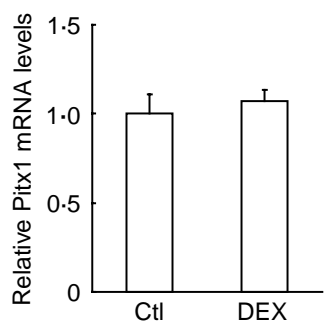

Figure 7 RT-PCR analysis of levels of POMC, Tpit and Pitx 1 mRNA in AtT-20 cells treated with DEX. RNA samples obtained from AtT20 cells treated with or without DEX $\left(10^{-7} \mathrm{M}, 24 \mathrm{~h}\right)$ were subjected by RT-PCR (A). After the PCR cycles, amplified products were analyzed (B-D). Amount of L19 mRNA was analyzed for internal control. Values are presented as means \pm s.E.M. of triplicate determinations. Experiments were replicated more than three times with separate batches of cell preparations. ${ }^{* * *} P<0 \cdot 001$, significantly different from control (Ctl) treatment group. well with previous reports (Philips et al. 1997a,b, Mynard et al. 2004). As mentioned above, luciferase activity of the pGL3Basic Vector was slightly increased by pCPT-cAMP treatment as much as POMC $-379 /+63$ and NurREmut constructs. Thus, the increase in promoter activity by pCPT-cAMP treatment shown with deletion and site-directed mutation of NurRE might have been a non-specific effect similar to that observed in the pGL3-Basic Vector.

In contrast to deletion of Tpit/PitxRE (POMC $-379 /+$ 63), the transcriptional activity of the site-directed mutation of TpitRE (POMC TpitREmut) was activated by $\mathrm{CRH}$ and pCPT-cAMP treatment as much as that of the wild-type construct, whereas the site-directed mutation of PitxRE (POMC PitxREmut) resulted in a loss of significant responsiveness to CRH but maintained responsiveness to pCPTcAMP. These results indicate that Tpit/PitxRE is not essential for $\mathrm{CRH}$ - and cAMP-induced POMC promoter activation in the intact rat POMC promoter context. Thus, $\mathrm{CRH}-$ and cAMP-induced activation of NurRE-mediated POMC transcription does not depend on the existence of Tpit/PitxRE.

$\mathrm{CRH}$ and $\mathrm{pCPT}$-cAMP treatments also enhanced luciferase activity of both tandem arrayed NurRE and Tpit/PitxRE reporter constructs $((\mathrm{NurRE}) \times 3$ and $($ Tpit/PitxRE $) \times 3$ constructs). These results suggest that Tpit/PitxRE as well as NurRE have responsiveness to $\mathrm{CRH} / \mathrm{cAMP}$ treatment consistent with previous reports (Kovalovsky et al. 2002, Maira et al. 2003b).

Treatment with inhibitors of the L-type calcium channel, CAM-KII, and calmodulin blunted CRH- and pCPTcAMP-induced activation of the Tpit/PitxRE construct as well as the NurRE construct. Calcium-dependent activation of NurRE has been described previously (Kovalovsky et al. 2002), and the present result also indicates that calcium acts as an intracellular second messenger for $\mathrm{CRH}-$ and cAMPinduced activation of Tpit/PitxRE. Tpit/PitxRE is also activated through PKA and MAPK pathways in AtT-20 cells (Maira et al. 2003b), and activation of the MAPK pathway by $\mathrm{CRH}$ and cAMP is inhibited by inhibitors of the L-type calcium channel and CAM-KII in AtT-20 cells (Kovalovsky et al. 2002), suggesting that MAPK activation is at least in part, calcium-dependent. Therefore, Tpit/PitxRE activation might require activation of a calcium/CAM-KII-mediated MAPK pathway, although it is possible that a MAPKindependent calcium/CAM-KII pathway, in part, leads to activation of Tpit/PitxRE.

The present findings, together with those from previous reports, suggest that activation of both NurRE and Tpit/PitxRE by CRH and cAMP is mediated through a similar signaling cascade. However, as mentioned above, in an intact rat POMC promoter context, Tpit/PitxRE does not appear to be essential for CRH/cAMP stimulation. Inter-dependence of NurRE and Tpit/PitxRE through a recruiting SRC co-activator in the transcription factor complex may be an important step for $\mathrm{CRH}$ stimulation of the POMC promoter (Maira et al. 2003b). Based on these findings, we postulate that in an intact POMC promoter 
context, Tpit/PitxRE is not necessarily an essential element for $\mathrm{CRH}$ and cAMP stimulation, but modulates responsiveness to $\mathrm{CRH}$ and cAMP.

Gcs are potent anti-inflammatory factors and such secretions from the adrenal cortex are enhanced by ACTH. POMC transcription and ACTH secretion are under the control of Gcs levels. This negative feedback loop is essential for the HPA axis, maintaining homeostasis including the stress response. In the present study, DEX repressed POMC promoter activity, but did not change the transcriptional activity of the empty plasmid (pGL3-Basic vector) or minimum rat POMC promoter (POMC $-34 /+63$ ), indicating a specific effect of DEX treatment on the repression of POMC transcription. Deletion and site-directed mutation experiments suggested that the target sequence of DEX repression of POMC transcription is Tpit/PitxRE, since the mutation of NurRE (POMC $-379 /+63$ and POMC NurREmut) retained DEX responsiveness while that of Tpit/PitxRE (POMC - 292/ + 63, POMC TpitREmut and POMC PitxREmut) abolished the same. The observation that activity of the tandem arrayed Tpit/PitxRE reporter is repressed by DEX treatment supports this idea. It is noteworthy that tandem repeat of NurRE is repressed by DEX treatment. Results from mutation of NurRE in an intact promoter context and tandem arrayed NurRE reporter in the present study led us to consider whether NurRE is required for the DEX-induced repression of POMC transcription. A recent study demonstrated that DEX antagonizes Nur factors/NurRE-dependent POMC transcription by protein-protein interaction between Nur factors and GR (Martens et al. 2005). The different observation between this previous report and ours might arise from different experimental procedure. Anyway, it seems that NurRE at least has responsiveness to Gcs upon CRH stimulation, and coordinates Tpit/PitxRE-dependent Gc repression of POMC transcription. Martens et al. (2005) also discussed the possibility of interdependence between NurRE and Tpit/PitxRE upon Gc repression of POMC transcription.

Tpit and Pitx1 mRNA levels were not influenced by DEX treatment, whereas POMC mRNA was decreased. These results suggest that transcriptional regulation of the $P O M C$ gene by Gcs is mediated through Tpit/PitxRE, but at transcription Gcs do not affect Tpit or Pitx1 expression. A possible explanation for the repressive effect of Gcs on POMC transcription is that the Gcs induce disassociation of $\mathrm{SRC} / \mathrm{p} 160$ co-activators from the POMC promoter. Tpit/PitxRE recruits SRC/p160 co-activators, resulting in an increase in POMC transcription (Maira et al. 2003b). On the other hand, GR interacts with SRC-2, which serves as a co-repressor at the AP-1 and NF- $\mathrm{NB}$ sites; a complex of GR and SRC-2 was shown to repress the transcriptional activity of AP-1 and NF- $\mathrm{B}$ (Rogatsky et al. 2002). In addition, interferon regulatory factor (IRF) 3 , which mediates the Tolllike receptor $3 / 4$ signaling pathway by utilizing SRC-2 as co-activator, competes with GR for binding to SRC-2. This competition between IRF3 and GR for SRC-2 results in the dissociation of SRC-2 from IRF3, followed by repression of IRF3-inducible genes (Reily et al. 2006). These findings suggest that Gcs may repress POMC transcription via the dissociation of SRC/p160 co-activators from the Tpit/ PitxRE activation complex. This interruption may also prevent interaction between Tpit and Nur factors, resulting in a transcriptional synergy between two factors. However, it has not yet been revealed whether Gc treatment changes the binding of Tpit and Pitx1 to Tpit/PitxRE, and further investigation is required to resolve these questions.

Another possible explanation for the Tpit/PitxREmediated Gc-induced repression of POMC transcription is that Tpit/PitxRE may be a possible binding site of GR, although the Tpit/PitxRE region in the POMC promoter was not identified as a GR-binding site (Drouin et al. 1989a). In this case, GR and Tpit/Pitx might compete for Tpit/ PitxRE, resulting in diminution of Tpit/PitxRE-dependent POMC transcription. In addition, it is possible that GR directly binds to Tpit and/or Pitx1, leading to a decrease in the transcriptional activity of Tpit and/or Pitx1 in a DNA binding-dependent or -independent manner. To assess the possibility mentioned above, analysis of the interaction between Tpit and GR or between Pitx1 and GR is therefore needed. Involvement of histone deacetylase (HDAC) 2 in Gc-induced repression of NurRE-mediated POMC transcription was recently reported (Bilodeau et al. 2006). Thus, further elucidation of the molecular mechanism behind Gc regulation of Tpit/PitxRE-mediated POMC transcription is required.

The POMC gene promoter possesses nGRE, which mediates Gc-induced gene repression (Drouin et al. 1989a). In our preliminary study, however, mutation of nGRE in the intact POMC promoter context did not alter responsiveness to DEX or basal promoter activity (data not shown). Therefore, the role of $\mathrm{nGRE}$ in the POMC promoter remains unknown.

Nudi et al. (2005) suggested that bone morphogenetic protein (BMP)-mediated repression of POMC transcription is mediated by interference of Tpit/PitxRE activity by molecular interaction between Smad and Tpit. The present study also revealed an important role of Tpit/PitxRE in POMC repression upon Gc stimulation. From this previous report and the data obtained here, Tpit/PitxRE appears to be a major regulatory sequence of POMC transcription, being a target DNA element of extracellular signaling molecules.

In conclusion, the present study suggests that Tpit/PitxRE in the POMC promoter has responsiveness to CRH and Gcs. Binding of Tpit and Pitx1 to the target sequence, Tpit/PitxRE, is required for maintaining basal levels of POMC transcription. Moreover, $\mathrm{CRH}$ was shown to enhance POMC transcription through NurRE activation, and during the NurRE activation, Tpit and Pitx1 may assist Nur factors with recruitment of SRC/p160 co-activators in a calcium-dependent manner. In Gc-induced repression of POMC transcription, Tpit/PitxRE was also shown to play a 
major role. Gcs repress the activity of Tpit/PitRE, through which the basal level of POMC transcription is maintained, leading to repressed POMC transcription. Tpit/PitxRE is therefore thought to mediate hormonal signals, cooperating with NurRE to maintain HPA function.

\section{Acknowledgements}

This study was supported by a Grant-in-aid from Japan Society for the Promotion of Science to S T. The authors declare that there is no conflict of interest that would prejudice the impartiality of this scientific work.

\section{References}

Affolter HU \& Reisine T 1985 Corticotropin releasing factor increases proopiomelanocortin messenger RNA in mouse anterior pituitary tumor cells. Journal of Biological Chemistry 260 15477-15481.

Aguilera G, Harwood JP, Wilson JX, Morell J, Brown JH \& Catt KJ 1983 Mechanisms of action of corticotropin-releasing factor and other regulators of corticotropin release in rat pituitary cells. Journal of Biological Chemistry 258 8039-8045.

Aoki Y, Iwasaki Y, Katahira M, Oiso Y \& Saito H 1997 Regulation of the rat proopiomelanocortin gene expression in AtT-20 cells. I: effects of the common secretagogues. Endocrinology 138 1923-1929.

Bilodeau S, Vallette-Kasic S, Gauthier Y, Figarella-Branger D, Brue T, Berthelet F, Lacroix A, Batista D, Stratakis C, Hanson J et al. 2006 Role of Brg1 and HDAC2 in GR trans-repression of the pituitary POMC gene and misexpression in Cushing disease. Genes and Development 20 2871-2886.

Birnberg NC, Lissitzky JC, Hinman M \& Herbert E 1983 Glucocorticoids regulate proopiomelanocortin gene expression in vivo at the levels of transcription and secretion. PNAS 80 6982-6986.

De Bosscher K, Vanden Berghe W \& Haegeman G 2003 The interplay between the glucocorticoid receptor and nuclear factor-kappaB or activator protein1: molecular mechanisms for gene repression. Endocrine Reviews 24 488-522.

Boutillier AL, Monnier D, Lorang D, Lundblad JR, Roberts JL \& Loeffler JP 1995 Corticotropin-releasing hormone stimulates proopiomelanocortin transcription by cFos-dependent and -independent pathways: characterization of an AP1 site in exon 1. Molecular Endocrinology 9 745-755.

Bruhn TO, Sutton RE, Rivier CL \& Vale WW 1984 Corticotropin-releasing factor regulates proopiomelanocortin messenger ribonucleic acid levels in vivo. Neuroendocrinology 39 170-175.

Cadepond F, Schweizer-Groyer G, Segard-Maurel I, Jibard N, Hollenberg SM, Giguere V, Evans RM \& Baulieu EE 1991 Heat shock protein 90 as a critical factor in maintaining glucocorticosteroid receptor in a nonfunctional state. Journal of Biological Chemistry $2665834-5841$.

Dostert A \& Heinzel T 2004 Negative glucocorticoid receptor response elements and their role in glucocorticoid action. Current Pharmacentical Design 10 2807-2816.

von Dreden G, Loeffler JP, Grimm C \& Hollt V 1988 Influence of calcium ions on proopiomelanocortin mRNA levels in clonal anterior pituitary cells. Neuroendocrinology 47 32-37.

Drouin J, Trifiro MA, Plante RK, Nemer M, Eriksson P \& Wrange O 1989a Glucocorticoid receptor binding to a specific DNA sequence is required for hormone-dependent repression of pro-opiomelanocortin gene transcription. Molecular and Cellular Biology 9 5305-5314.

Drouin J, Nemer M, Charron J, Gagner JP, Jeannotte L, Sun YL, Therrien M $\&$ Tremblay Y $1989 b$ Tissue-specific activity of the pro-opiomelanocortin (POMC) gene and repression by glucocorticoids. Genome 31 510-519.

Eberwine JH \& Roberts JL 1984 Glucocorticoid regulation of proopiomelanocortin gene transcription in the rat pituitary. Journal of Biological Chemistry 259 2166-2170.
Farrell WE, Stewart MF, Clark AJ, Crosby SR, Davis JR \& White A 1993 Glucocorticoid inhibition of ACTH peptides: small cell lung cancer cell lines are more resistant than pituitary corticotroph adenoma cells. Journal of Molecular Endocrinology 10 25-32.

Gagner JP \& Drouin J 1985 Opposite regulation of pro-opiomelanocortin gene transcription by glucocorticoids and CRH. Molecular and Cellular Endocrinology 40 25-32.

Gagner JP \& Drouin J 1987 Tissue-specific regulation of pituitary proopiomelanocortin gene transcription by corticotropin-releasing hormone, $3^{\prime}, 5^{\prime}$-cyclic adenosine monophosphate, and glucocorticoids. Molecular Endocrinology 1 677-682.

Giguere V, Labrie F, Cote J, Coy DH, Sueiras-Diaz J \& Schally AV 1982 Stimulation of cyclic AMP accumulation and corticotropin release by synthetic ovine corticotropin-releasing factor in rat anterior pituitary cells: site of glucocorticoid action. PNAS 79 3466-3469.

Grammatopoulos DK \& Chrousos GP 2002 Functional characteristics of $\mathrm{CRH}$ receptors and potential clinical applications of CRH-receptor antagonists. Trends in Endocrinology and Metabolism 13 436-444.

Hammer GD, Fairchild-Huntress V \& Low MJ 1990 Pituitary-specific and hormonally regulated gene expression directed by the rat proopiomelanocortin promoter in transgenic mice. Molecular Endocrinology 4 1689-1697.

Jeannotte L, Trifiro MA, Plante RK, Chamberland M \& Drouin J 1987 Tissue-specific activity of the pro-opiomelanocortin gene promoter. Molecular and Cellular Biology 7 4058-4064.

Keller-Wood ME \& Dallman MF 1984 Corticosteroid inhibition of ACTH secretion. Endocrine Reviews 5 1-24.

Kovalovsky D, Refojo D, Liberman AC, Hochbaum D, Pereda MP, Coso OA, Stalla GK, Holsboer F \& Arzt E 2002 Activation and induction of NUR77/NURR1 in corticotrophs by CRH/cAMP: involvement of calcium, protein kinase A, and MAPK pathways. Molecular Endocrinology 16 1638-1651.

Kumar R \& Thompson EB 2005 Gene regulation by the glucocorticoid receptor: structure:function relationship. Journal of Steroid Biochemistry and Molecular Biology 94 383-394.

Kuryshev YA, Childs GV \& Ritchie AK 1996 Corticotropin-releasing hormone stimulates $\mathrm{Ca}^{2+}$ entry through $\mathrm{L}$ - and P-type $\mathrm{Ca}^{2+}$ channels in rat corticotropes. Endocrinology 137 2269-2277.

Lamolet B, Pulichino AM, Lamonerie T, Gauthier Y, Brue T, Enjalbert A \& Drouin J 2001 A pituitary cell-restricted T box factor, Tpit, activates POMC transcription in cooperation with Pitx homeoproteins. Cell 104 849-859.

Lee AK \& Tse A 1997 Mechanism underlying corticotropin-releasing hormone $(\mathrm{CRH})$ triggered cytosolic $\mathrm{Ca}^{2+}$ rise in identified rat corticotrophs. Journal of Physiology 504 367-378.

Litvin Y, PasMantier R, Fleischer N \& Erlichman J 1984 Hormonal activation of the cAMP-dependent protein kinases in AtT20 cells. Preferential activation of protein kinase I by corticotropin releasing factor, isoproterenol, and forskolin. Journal of Biological Chemistry 259 10296-10302.

Liu B, Hammer GD, Rubinstein M, Mortrud M \& Low MJ 1992 Identification of DNA elements cooperatively activating proopiomelanocortin gene expression in the pituitary glands of transgenic mice. Molecular and Cellular Biology 12 3978-3990.

Loeffler JP, Kley N, Pittius CW \& Hollt V 1986 Calcium ion and cyclic adenosine $3^{\prime}, 5^{\prime}$-monophosphate regulate proopiomelanocortin messenger ribonucleic acid levels in rat intermediate and anterior pituitary lobes. Endocrinology 119 2840-2847.

Maira M, Martens C, Philips A \& Drouin J 1999 Heterodimerization between members of the Nur subfamily of orphan nuclear receptors as a novel mechanism for gene activation. Molecular and Cellular Biology 19 7549-7557.

Maira M, Martens C, Batsche E, Gauthier Y \& Drouin J 2003a Dimer-specific potentiation of NGFI-B (Nur77) transcriptional activity by the protein kinase A pathway and AF-1-dependent coactivator recruitment. Molecular and Cellular Biology 23 763-776.

Maira M, Couture C, Le Martelot G, Pulichino AM, Bilodeau S \& Drouin J $2003 b$ The T-box factor Tpit recruits SRC/p160 co-activators and mediates hormone action. Journal of Biological Chemistry 278 46523-46532.

Martens C, Bilodeau S, Maira M, Gauthier Y \& Drouin J 2005 ProteinProtein interactions and transcriptional antagonism between the subfamily of NGFI-B/Nur77 orphan nuclear receptors and glucocorticoid receptor. Molecular Endocrinology 19 885-897. 
Mynard V, Latchoumanin O, Guignat L, Devin-Leclerc J, Bertagna X, Barre B, Fagart J, Coqueret O \& Catelli MG 2004 Synergistic signaling by corticotropin-releasing hormone and leukemia inhibitory factor bridged by phosphorylated $3^{\prime}, 5^{\prime}$-cyclic adenosine monophosphate response element binding protein at the Nur response element (NurRE)-signal transducers and activators of transcription (STAT) element of the proopiomelanocortin promoter. Molecular Endocrinology 18 2997-3010.

Nikodemova M, Kasckow J, Liu H, Manganiello V \& Aguilera G 2003 Cyclic adenosine $3^{\prime}, 5^{\prime}$-monophosphate regulation of corticotropin-releasing hormone promoter activity in AtT-20 cells and in a transformed hypothalamic cell line. Endocrinology 144 1292-1300.

Nudi M, Ouimette JF \& Drouin J 2005 BMP (Smad)-mediated repression of POMC transcription by interference with Pitx/Tpit activity. Molecular Endocrinology 19 1329-1342.

Philips A, Lesage S, Gingras R, Maira MH, Gauthier Y, Hugo P \& Drouin J $1997 a$ Novel dimeric Nur77 signaling mechanism in endocrine and lymphoid cells. Molecular and Cellular Biology 17 5946-5951.

Philips A, Maira M, Mullick A, Chamberland M, Lesage S, Hugo P \& Drouin J 1997b Antagonism between Nur77 and glucocorticoid receptor for control of transcription. Molecular and Cellular Biology 17 5952-5959.

Picard D \& Yamamoto KR 1987 Two signals mediate hormonedependent nuclear localization of the glucocorticoid receptor. EMBO Journal 6 3333-3340.

Pulichino AM, Vallette-Kasic S, Tsai JP, Couture C, Gauthier Y \& Drouin J $2003 a$ Tpit determines alternate fates during pituitary cell differentiation. Genes and Development 17 738-747.

Pulichino AM, Vallette-Kasic S, Couture C, Gauthier Y, Brue T, David M, Malpuech G, Deal C, Van Vliet G, De Vroede M et al. $2003 b$ Human and mouse TPIT gene mutations cause early onset pituitary ACTH deficiency. Genes and Development 17 711-716.
Ray DW, Ren SG \& Melmed S 1996 Leukemia inhibitory factor (LIF) stimulates proopiomelanocortin (POMC) expression in a corticotroph cell line. Role of STAT pathway. Journal of Clinical Investigation $\mathbf{9 7}$ 1852-1859.

Reily MM, Pantoja C, Hu X, Chinenov Y \& Rogatsky I 2006 The GRIP1:IRF3 interaction as a target for glucocorticoid receptor-mediated immunosuppression. EMBO Journal 25 108-117.

Reisine T, Rougon G, Barbet J \& Affolter HU 1985 Corticotropin-releasing factor-induced adrenocorticotropin hormone release and synthesis is blocked by incorporation of the inhibitor of cyclic AMP-dependent protein kinase into anterior pituitary tumor cells by liposomes. PNAS $\mathbf{8 2}$ $8261-8265$.

Rogatsky I, Luecke HF, Leitman DC \& Yamamoto KR 2002 Alternate surfaces of transcriptional coregulator GRIP1 function in different glucocorticoid receptor activation and repression contexts. PNAS 99 16701-16706.

Timpl P, Spanagel R, Sillaber I, Kresse A, Reul JM, Stalla GK, Blanquet V, Steckler T, Holsboer F \& Wurst W 1998 Impaired stress response and reduced anxiety in mice lacking a functional corticotropin-releasing hormone receptor 1. Nature Genetics 19 162-166.

Vita N, Laurent P, Lefort S, Chalon P, Lelias JM, Kaghad M, Le Fur G, Caput D \& Ferrara P 1993 Primary structure and functional expression of mouse pituitary and human brain corticotrophin releasing factor receptors. FEBS Letters 335 1-5.

Received in final form 6 March 2007

Accepted 12 March 2007

Made available online as an Accepted Preprint 13 March 2007 